\title{
Analisis Gaya Kepemimpinan Radio Komunitas SAKA FM di Yogyakarta
}

\author{
Elok Kharismatul Ula \\ Megister Media dan Komunikasi Universitas Airlangga \\ E-mail: elok.kharisma4@gmail.com
}

DOI: https://doi.org/10.21107/ilkom.v15i2.11491

\begin{abstract}
ABSTRAK
Pada penelitian ini penulis bertujuan untuk mengetahui gaya kepemimpinan yang digunakan oleh station manager Radio Komunitas SAKA FM. SAKA FM merupakan radio komunitas yang ada di Kauman, Ngupasan, Kecamatan Gondomanan, Yogyakarta. Berdiri sejak 1 April 2012, mengudara pada frekuensi 107.9 Mhz dan mempunyai sapaan untuk anggota yang ada di SAKA FM ini adalah Balaswara. Metodologi penelitian yang penulis gunakan ialah pendekatan kualitatif dengan jenis penelitian deskriptif. Metodologi ini diyakini dapat menggambarkan gaya komunikasi dari station manager radio komunitas SAKA FM. Selanjutnya, untuk metode penelitian yang digunakan adalah studi kasus. Pengumpulan data menggunakan pengumpulan data primer, berupa wawancara dengan manajer dan salah satu penyiar SAKA FM, serta untuk data sekunder dengan mengumpulkan dokumen-dokumen sejarah radio komunitas SAKA FM. Teknis analisis data kualitatif melalui Miles dan Huberman dengan tahapan antara lain, reduksi data, penyajian data dan penarikan kesimpulan. Uji keabsahan data menggunakan triangulasi. Hasil penelitian menunjukkan bahwa station manager mempunyai peran penting untuk mencapai tujuan suatu organisasi, baik mengelola sumber daya manusia dan produknya. Oleh karena itu gaya kepemimpinan sangatlah penting diterapkan oleh seorang pemimpin, gaya kepemimpinan yang digunakan oleh station manager SAKA FM adalah gaya tim (team style). Gaya ini dicirikan dengan manajer perhatian terhadap produk dan manusianya. Station Manager ini telah perhatian kepada penyiar, memantau perkembangan radio komunitasnya, menjaga interaksi, memberikan motivasi. Proses pengambilan keputusan pun juga berdasarkan pertimbangan atau masukan dari divisi lainnya.
\end{abstract}

Kata Kunci: Gaya Kepemimpinan, Gaya Tim, Radio Komunitas, SAKA FM, Station Manager

\section{ABSTRACT}

In this study, the author aims to determine the leadership style which is used by the manager station of SAKA FM Community Radio. SAKA FM is a community radio which is located in Kauman, Ngupasan, Gondomanan District, Yogyakarta. Established since 1st of April 2012, broadcasts on a frequency of 107.9 Mhz and has a greeting for all members in SAKA FM, is Balaswara. The research methodology that the author uses is a qualitative approach with a descriptive research type. This methodology is believed to be able to describe the communication style of the SAKA FM community radio manager station. Furthermore, for the methodology research uses here is a case study. Collecting data uses primary data collection, in the form of interviews with the manager and one of the announcers of SAKA FM, as well as for secondary data

Cite this as :

Ula, Elok Kharismatul (2021). Analisis Gaya Kepemimpinan Radio Komunitas SAKA FM di Yogyakarta. Jurnal Komunikasi, 15(2), 145-156. doi: https://doi.org/10.21107/ilkom.v15i2.11491
Article History :

Received August, $15^{\text {th }}$ 2021, Acepted September, $4^{\text {th }} 2021$ 
by collecting historical documents of SAKA FM community radio. Technical analysis of qualitative data through Miles and Huberman with stages, among others, data reduction, data presentation and drawing conclusions. Test the validity of the data using triangulation. The results are showed that the manager station has an important role to achieve the goals of an organization, both managing human resources and products. Therefore, the leadership style is very important to be applied by a leader, the leadership style is used by the SAKA FM manager station is team style. This style is characterized by the manager's concern for the product and its people. This Manager Station has been paying attention to broadcasters, monitoring the development of his community radio, maintaining interaction, providing motivation. The decisionmaking process is also based on considerations or input from other divisions.

Keywords: Leadership style, Team style, Community Radio, SAKA FM, Manager Station

\section{PENDAHULUAN}

Kegagalan ataupun kesuksesan organisasi bisa terjadi akibat peran pemimpin dalam mengelola organisasinya. Mengutip dalam Wahab (2015: 3) kepemimpinan menjadi salah satu faktor untuk mengubah dan mengembangkan sebuah organisasi. Beberapa kasus kegagalan pemimpin telah mencuat ke permukaan, diberitakan oleh BBC News Indonesia (2017) bahwa terdapat 2 pimpinan Pertamina yang dicopot jabatannya karena tidak bisa bekerja sama. Menteri Badan Usaha Miik Negara, Rini Soemarno memutuskan mencopot jabatan pimpinan Pertamina yaitu Direktur Utama Dwi Soetjipto dan Wakil Direktur Utama Ahmad Bambang.

Kasus mengenai kepemimpinan ini muncul juga pada perusahaan Nokia. Tidak dipungkiri pada tahun 1990-an hingga 2000an bahwa Nokia pernah menjadi perusahaan ponsel yang besar seakan tidak bisa dikalahkan. Namun kesuksesan nya mulai mengendur saat Apple memperkenalkan produk iPhone pada tahun 2007. Mengutip dalam laman berita Kompas (2021) memang cukup kompleks faktor yang mendasari kebangkrutan Nokia, akan tetapi beberapa peneliti menyorot ada tiga hal utama dari faktor internal yang mendasari, yaitu kalahnya kualitas teknologi dari Apple, arogansi jajaran manajer dan visi perusahaan yang lemah.

Pada penelitian ini menggunakan radio komunitas sebagai organisasi yang diteliti. Menurut Jaringan Radio Komunitas Yogyakarta dalam website nya menjelaskan radio komunitas yaitu siaran radio yang dimiliki, didirikan, diinisiatifkan, dikelola, diperuntukkan oleh sebuah komunitas. Lembaga penyiaran komunitas sebagai pelaksana penyiaran komunitas. Merujuk dalam UU No.32 Tahun 2002 tentang Penyiaran, pada pasal 21 ayat (1) Lembaga Penyiaran Komunitas sebagaimana dimaksud dalam Pasal 13 ayat (2) huruf c merupakan lembaga penyiaran yang berbentuk badan hukum Indonesia, didirikan oleh komunitas tertentu, bersifat independen, dan tidak komersial dengan daya pancar rendah, luas jangkauan wilayah terbatas, serta untuk melayani kepentingan komunitasnya. Peranan radio komunitas tertulis dalam pada pasal 21 ayat (2) huruf b, untuk mendidik dan memajukan masyarakat dalam mencapai kesejahteraan, dengan melaksanakan program acara yang meliputibudaya, pendidikan, dan informasi yang menggambarkan identitas bangsa.

Radio Komunitas ini banyak pula bermunculan di Daerah Istimewa Yogyakarta. Mengutip dalam website Jaringan Radio Komunitas Yogyakarta (JRKY) terdapat kurang lebih 61 radio komunitas yang tergabung. Terbentuknya radio komunitas ini tentu dengan tujuan yang berbeda-beda serta membawa visi dan misi nya masing-masing. Salah satu radio komunitas yang tergabung dalam JRKY adalah radio komunitas SAKA FM.

Sebuah radio komunitas, tentu secara struktur kepengurusan ada seorang pemimpin atau dalam radio komunitas ini disebut station manager. Mengutip dalam Madiistriyatno (2019: 1) pemimpin merupakan orang yang 
mempunyai kemampuan memimpin, berarti seorang pemimpin memiliki kemampuan memengaruhi orang ataupun komunitas tanpa mengindahkan suatu bentuk alasan. Pemimpin juga diartikan sebagai manusia yang mempunyai amanah memimpin subordinat atau pengikutnya untuk mencapai amanah yang ditentukan tersebut. Oleh karena itu, pemimpin yang mempunyai jiwa kepemimpinan tinggi pastinya harus bisa mengelola seluruh elemen dalam suatu organisasi dengan baik dan benar. Pemimpin dituntut untuk mempunyai wawasan tinggi, kepercayaan diri dan harus bisa bersosialisasi.

Pemimpin jika dalam bahasa inggris menjadi "Leader" yang tugasnya me-LEAD anggotanya. Makna LEAD adalah, huruf L diartikan loyality, pemimpin harus mampu memberi dan membangkitkan loyalitas rekan kerjanya. Kemudian huruf E yaitu sebagai educate dimana pemimpin harus bisa mengedukasi rekannya serta bisa mewariskan tacit knowledge. Huruf A berarti advice yaitu memberikan saran dan nasihat dari permasalahan yang terjadi. Terakhir adalah huruf D (discipline) dengan memberikan contoh dan menegakkan kedisiplinan dalam setiap aktivitas (Madiistriyatno, 2019: 3-4).

Menyoal tentang kepemimpinan sendiri, mengutip dalam Madiistriyatno (2019: 11) kepemimpinan diartikan sebagai kemampuan untuk memengaruhi perilaku seseorang ataupun kelompok untuk mencapai tujuan tertentu dalam situasi tertentu. Jika menurut Miller, (2012: 188) Pemikiran awal bahwa para pemimpin "dilahirkan, bukan dibuat" tercermin dalam teori sifat kepemimpinan. Menurut Northhouse (1997) dalam Miller (2012), menerangkan sejumlah studi tentang sifat dan karakteristik kepemimpinan secara umum yaitu, kecerdasan (kemampuan verbal, kemampuan persepsi dan penalaran), kepercayaan diri, tekad, integritas, kemampuan bersosialisasi.

Dalam melaksanakan peranan menjadi seorang pemimpin, maka pemimpin menerapkan gaya kepemimpinan tertentu. Seorang pemimpin diberikan kebebasan dalam menerapkan berbagai macam pendekatan ataupun gaya kepemimpinan, yang nantinya ini menjadi ciri khas dari pemimpin (Latifah, 2021: 235). Dengan gaya kepemimpinan yang dipilih akan memperoleh manfaat untuk digunakan sebagai pedoman dalam memimpin bawahan nya, gaya kepemimpinan juga sebagai norma seseorang saat mencoba untuk memengaruhi perilaku orang lain (Madiistriyatno, 2019: 25).

Guna menganalisis gaya kepemimpinan, penulis mengutip dari Madiistriyatno (2019: 50) gaya kepemimpinan yang populer dari masa lalu dikategorikan dalam klasifikasi gaya kepemimpinan Manajerial Grid dari Robert R. Blake dan Jane S. Mouton. Blake dan Jane S. Mouton mencirikan gaya kepemimpinan dalam empat gaya ekstrim, lalu ditambah satu gaya yang berada di tengah dengan tujuan menyeimbangkan empat gaya yang berada diberbagai sisi.

Konsep gaya Blake dan Mouton lebih lengkap nya dijelaskan Miller (2012: 49) Blake dan Mouton membedakan lima gaya manajemen prototipikal. Gaya Pengalah (impoverished style). Manajer seperti itu tidak terlalu mementingkan tujuan dari organisasi ataupun orang yang terlibat didalam nya serta manajer tipe ini melakukan tindakan yang minimum untuk mempertahankan. Mengutip dalam Rumondor (2011: 30) ciri manajer pada tipe ini adalah kurangnya perhatian terhadap produksi. Pemimpin cenderung lemah dalam menerima keputusan orang lain, menyetujui pendapat, sikap, ataupun gagasan orang lain. Apabila dalam organisasi terjadi konflik, pemimpin jenis ini tetap netral dan memilih berdiri diluar masalah.

Gaya santai (country club style). Manajer tipe ini dicirikan dengan tingginya kepedulian terhadap orang-orang dalam organisasi, namun perhatian rendah pada produksi. Hubungan yang baik sangat penting bagi pemimpin ini, seperti hal nya suka menerima pendapat, perilaku ataupun ide dari orang lain. Lebih suka untuk menghindari konflik, tapi bila konflik terjadi tindakan nya 
adalah melunakkan perasaan orang dan mencoba menjaga agar mereka tetap bekerja sama. Pemimpin gaya santai, bersikap hangat, ramah karena ingin mengurangi ketegangan dalam gangguan yang terjadi. Sikap menolong lebih tinggi daripada sikap memimpin (Rumondor, 2011: 32)

Gaya Pemimpin Pertengahan (middleof-the-road style). Dalam Miller (2012: 50) gaya ini ditandai oleh manajer yang berusaha menyeimbangan perhatian terhadap orang dan produksi. Mengutip dalam Rumondor (2011: 30) Jika terjadi perbedaan dalam pendapat, ide, ataupun sikap, pemimpin gaya pertengahan berusaha untuk jujur dan tegas untuk mencari pemecahan yang tidak memihak. Menghindari ketegangan akan dilakukan saat terjadi konflik dalam organisasi., karena ingin mempertahankan agar tetap dalam keadaan baik.

Gaya Tim (Team Style). Pemimpin ini identik dengan perhatian yang tinggi terhadap tugas dan manusia. Keputusan yang logis, kreatif hasil dari kesepakatan bersama akan sangat dihargai oleh pemimpin gaya ini. Meskipun adanya perbedaan ide, sikap pemimpin gaya ini akan tetap didengarkan. Keyakinan kuat terhadap apa yang harus dilakukan namun tetap memberi respon pada pemikiran orang lain yang logis dengan mengubah pendapatnya. Jika terjadi konflik, pemimpin tim akan mencari penyebabnya serta memeriksa alasan yang mendasari perbedaan. Dalam keadaan marah, seorang pemimpin tim bisa mengendalikan dirinya meskipun kadang terlihat jengkel. Rasa humor nya tinggi meskipun dalam tekanan, dan lebih menunjukkan usaha keras serta mengikutsertakan orang lain untuk bergabung bersamanya. Saling mempercayai dan saling menghargai sesama anggota tim menjadi hal yang melekat pada pemimpin gaya tim (Rumondor, 2011:31)

\section{Gaya Otoriter (Authority Compliance)} dalam Miller (2012: 49) pemimpin ini ditandai dengan adanya perhatian yang tinggi terhadap produksi, tetapi perhatian rendah terhadap manusia didalam nya. Manajer ini seperti manajer ilmiah dan manajemen klasik, karena cenderung mengatur semua komponen yang ada di tempat kerja, termasuk orang, memaksimalkan efisiensi dan mencapai tujuan. Kebutuhan manusia nya hanya sedikit diperhatikan.

Penelitian tentang gaya kepemimpinan ini sudah pernah dilakukan sebelumnya pada berbagai organisasi. Penelitian terdahulu yang pertama dilakukan oleh Adrian Hartanto pada tahun 2016 dengan judul "Analisis Gaya Kepemimpinan Pada PT. Sinar Sarana Sukses". Penelitian yang dilakukan oleh Hartanto bertujuan agar mengetahui gaya kepemimpinan yang selama ini diterapkan oleh direktur PT. Sinar Sarana Sukses Surabaya. Pendekatan penelitian dilakukan secara kualitatif dengan jenis deskriptif. Dengan metode penelitian yang dilakukan, dihasilkan bahwa direktur dari PT. Sinar Sarana Sukses menggunakan gaya partisipatif, dibuktikan dengan pemberian wewenang serta tanggung jawab kepada karyawan berdasarkan jabatannya. Kemudian berdasarkan pengambilan keputusan, direktur selalu melibatkan ide maupun berbagai saran dari karyawan nya, serta direktur selalu mempunyai cara untuk menumbuhkan rasa loyalitas kepada karyawan nya. Persamaan dengan penelitian yang penulis lakukan adalah teori yang digunakan adalah gaya kepemimpinan, serta penggunaan pendekatan penelitian juga kualitatif deskriptif. Tetapi letak perbedaannya adalah penulis meneliti pada station manager dari radio komunitas SAKA FM.

Penelitian terdahulu yang kedua adalah dengan judul "Eksistensi dan Gaya Kepemimpinan Radio Lokal", penelitian dari Anna Puji Lestari dan Sunanto, mahasiswa Universitas Diponegoro Semarang. Pada penelitian ini radio lokal yang dimaksud adalah Radio Idola FM di Semarang. Pokok pembahasan disini ada 2, yaitu terkait eksistensi, dan gaya kepemimpinan yang diterapkan dalam Radio Idola FM Semarang. Setelah mengetahui bagaimana eksistensi dari radio tersebut, penulis pada penelitian terdahulu ini mengkorelasikan antara 
eksistensi dan gaya kepemimpinan yang diterapkan. Hasil penelitiannya menunjukkan bahwa eksistensi Radio Idola FM didukung dengan gaya kepemimpinan. Gaya kepemimpinan yang digunakan adalah dengan mendorong semangat karena direktur menganggap bawahan (karyawan) sebagai aset perusahaan (Lestari dan Sunanto, 2018: 112). Persamaan dengan penelitian yang penulis lakukan adalah sama mengangkat gaya kepemimpinan pada organisasi radio, serta pendekatan penelitian juga kualitatif. Kemudian perbedaannya adalah penelitian terdahulu mengkorelasikan antara eksistensi dan gaya kepemimpinan. Namun pada penelitian yang penulis lakukan berfokus pada identifikasi gaya kepemimpinan yang diterapkan di Radio Komunitas SAKA FM.

Kajian mengenai station manager radio komunitas juga pernah dilakukan dalam jurnal berjudul "Peranan Station Manager dalam Mengembangkan Radio Komunitas di Politeknik LP3I Bandung" yang ditulis oleh Adi Muhammad Ramadhan pada tahun 2019. Dalam penelitian nya bertujuan untuk mengetahui kaitan peranan seorang station manager dalam mengembangkan radio komunitas. Menggunakan metode penelitian deskriptif dengan observasi, wawancara dan studi kepustakaan. Hasil penelitian menunjukkan bahwa seorang station manager dalam proses mengembangkan suatu radio komunitas agar bisa diterima masyarakat diperlukan rasa tanggung jawab yang tinggi agar semua dapat terkendali sesuai dengan harapan. Persamaan dengan penelitian yang penulis lakukan adalah sama mengambil station manager pada radio komunitas, namun perbedaannya penulis menekankan pada analisis gaya kepemimpinan yang dilakukan oleh station manager.

Tujuan dilakukan penelitian ini untuk mengidentifikasi tentang gaya kepemimpinan di Radio Komunitas Saka FM, radio yang terletak di lingkungan Masjid Gede Kauman Yogyakarta. Radio Komunitas SAKA FM merupakan radio yang berbasis warga kampung Kauman Yogyakarta, mengudara pada frekuensi 107.9 Mhz. Segmentasi siaran radio ini yaitu hiburan, edukasi dan religi. Karena radio ini diharapkan bisa memotivasi masyarakat Kauman dengan informasiinformasi dan hiburan yang cerdas, dan tentunya sekaligus dalam urusan dakwah keislaman.

Penelitian gaya komunikasi di SAKA FM ini penting dilakukan, mengingat sumber daya manusia yang terlibat dalam Radio Komunitas SAKA FM ini sangat beragam. Tidak hanya dari masyarakat Kauman Yogyakarta saja, melainkan dari berbagai daerah, karena radio komunitas ini melibatkan mahasiswa-mahasiswa yang kuliah di Yogyakarta. Maka dari itu beragam latar belakang sosial dan pendidikan juga ada didalamnya. Urgensi penelitian lainnya adalah dengan meningkatnya teknologi komunikasi dan informasi akankah dimanfaatkan olehh manager SAKA FM untuk berkomunikasi. Mengingat gaya kepemimpinan juga termasuk dalam membangun komunikasi yang baik dengan semua orang yang terlibat dalam organisasi tersebut.

Meneliti gaya kepemimpinan di radio SAKA FM penting untuk diteliti, apalagi SAK FM saat ini sudah membuka magang untuk mahasiswa Yogyakarta. Sehingga semakin banyak orang yang terlibat dalam organisasi tersebut. Radio SAKA FM memang dibawah naungan Masjid Gede Kauman, tanggung jawabnya mengedukasi masyarakat. Sehingga perlu diketahui gaya kepemimpinan manager SAKA FM dalam memikirkan kepentingan berbagai pihak dengan diiringi kualitas produksi yang baik. Penelitian ini dapat memperlihatkan dengan jelas gaya kepemimpinan dalam organisasi radio komunitas. Hal ini tentu menjadi kebaruan apalagi memimpin ditengah pesatnya perkembangan informasi teknologi dan komunikasi.

Terlaksananya penelitian ini diharapkan memberikan manfaat secara praktis maupun akademis. Manfaat praktis, tentu menambah wawasan mengenai penerapan gaya kepemimpinan dalam suatu 
organisasi, bertemu dengan relasi-relasi baru. Manfaat secara akademis dapat digunakan untuk menjadi rujukan pada penelitian gaya kepemimpinan di organisasi lain, ataupun pengembangan teori gaya kepemimpinan kaitannya dengan kepuasan kerja, motivasi kerja dan lain sebagainya.

\section{METODE PENELITIAN}

Penelitian kali ini merupakan jenis penelitian kualitatif. Penelitian kualitatif merupakan penelitian yang dapat dihasilkan melalui kata-kata, tulisan atau lisan dari pelaku yang diamati (Creswell, 2009). Datadata yang ada diperoleh melalui lapangan/pengamatan langsung. Pendekatan penelitian yang digunakan yakni pendekatan fenomenologi. Pendekatan fenomenologi berusaha memahami orang-orang dalam situasi tertentu yang ada kaitannya dengan suatu fenomena/peristiwa.

Pada
menggunakan
pendekatan ini $\begin{gathered}\text { penulis } \\ \text { penelitian }\end{gathered}$ kualitatif. Mengutip dalam penjelasan Yusuf (2017: 43) pendekatan kualitatif bisa digunakan jika ingin melihat suatu keadaan ataupun suatu objek dalam konteksnya, untuk menemukan makna atau pemahaman mendalam pada suatu masalah yang dihadapi. Penggunaan pendekatan kualitatif diyakini dapat mengungkap gaya kepemimpinan yang dilakukan oleh station manager radio komunitas SAKA FM. Dalam mendapatkan mengenai gaya kepemimpinan ini tentu digunakan pencarian secara mendalam.

Penulis menggunakan jenis kualitatif deskriptif. Tujuan menggunakan kualitatif deskriptif adalah membuat deskripsi secara sistematis, akurat dan faktual tentang faktafakta dan sifat-sifat populasi atau objek tertentu. Riset ini tentunya untuk memperlihatkan realitas yang sedang terjadi tanpa menjelaskan hubungan antar variabel (Kriyantono, 2014: 69). Pada penelitian ini penulis menggunakan metode penelitian dengan studi kasus, dalam Kriyantono (2014:
65) dijelaskan bahwa dalam proses penelitian studi kasus cenderung menggunakan berbagai sumber data, selanjutnya menguraikan serta menjelaskan dengan detail pada berbagai aspek individu, kelompok, suatu program, organisasi ataupun peristiwa sistematis.

Metode pengumpulan data menggunakan sumber primer dan sumber sekunder. Mengutip dari Hardani, dkk (2020: 103) sumber primer berkaitan dengan dokumen ataupun bahan yang dijelaskan langsung oleh orang atau pihak yang ada pada waktu kejadian yang digambarkan. Sumber primer ini dilakukan dengan wawancara terstruktur, artinya wawancara berlangsung sesuai dengan pedoman pertanyaan yang sudah disiapkan (Rahmadi, 2011: 75). Sumber sekunder, sumber kajian yang dapat digambarkan oleh orang yang bukan mengalami ataupun hadir saat waktu kejadian (Hardani, dkk, 2020: 104). Sumber sekunder ini berupa dokumen pendukung, seperti dokumen visi-misi SAKA FM dan lain sebagainya

Fokus penelitian berguna sebagai batasan masalah agar penelitian ini tetap terarah sesuai dengan tujuan yang sudah dibahas pada pendahuluan. Sesuai dengan judul yang sudah penulis pilih, penulis berfokus pada gaya kepemimpinan yang digunakan oleh station manager di Radio Komunitas SAKA FM yang ada di Yogyakarta. Oleh karena itu subjek penelitiannya adalah station manager tersebut, ditambah penyiar nya agar memperkuat temuan yang diperoleh.

Teknik analisis data pada penelitian ini adalah menggunakan konsep Miles dan Huberman, dimana terdapat tiga aktivitas yang terdiri dari reduksi data, penyajian data dan menarik kesimpulan atau verifikasi (Rusmini, 2017: 105). Reduksi data adalah bagian dari analisis dengan menggolongkan, mengarahkan atau membuang yang tidak perlu, mengordinasikan data agar dapat ditarik kesimpuan dan verifikasi (Hardani, dkk, 2020: 164). Penyajian data berisikan informasi yang sudah tersusun sehingga 
memungkinkan untuk penarikan kesimpulan dan pengambilan tindakan. Penyajian dalam kualitatif ini berupa teks naratif (Hardani, dkk, 2020: 165). Penarikan simpulan dan verifikasi ini berkaitan dengan intisari dari temuan penelitian yang menggambarkan pendapat terakhir berdasarkan uraian-uraian sebelumnya atau berdasarkan metode berpikir induktif-deduktif (Hardani, dkk, 2020: 171).

Uji keabsahan data menggunakan analisis triangulasi, yaitu menganalisis jawaban subjek dengan meneliti kebenarannya dengan data empiris (sumber data lainnya) yang tersedia. Di sini jawaban subjek di cross-check dengan dokumen yang ada. (Kriyantono, 20014:72).

\section{HASIL DAN PEMBAHASAN}

\section{Hasil Penelitian}

Radio Komunitas SAKA FM adalah radio yang berbasis warga kampung Kauman Yogyakarta. Berdiri sejak 1 April 2012. Radio Saka FM Jogja berjalan cukup efektif dan selalu berproses merangkul warga untuk terlibat langsung dalam kegiatan radio komunitas di frekuensi 107.9 Mhz. Berawal dari sebuah ide untuk memberi sebuah media inspirasi dan aspirasi warga melalui silaturahim lewat udara yang berawal di tahun 80'an namun akhirnya baru terealisir 30 tahun kemudian. Radio Saka FM ini sudah berfungsi jamak bagi warga kauman yang selain kampung religi juga merupakan kampung budaya baik sebagai media hiburan, informasi, edukasi dan dakwah.

Dukungan masyarakat dan pemerintah Kalurahan setempat terhadap SAKA FM semakin bertambah karena Radio SAKA FM merupakan radio warga yang dibangun dan dikembangkan oleh warga maka Iklan Layanan Masyarakat maupun iklan dukungan acara di Radio SAKA FM pada dasarnya tidak ditarif. Para pengusaha lokal yang mempromosikan produk barang dan jasa memberikan kontribusi dan berupa sebagaimana halnya radio komersial, partisipasi secara sukarela. Kehadiran Radio Komunitas SAKA FM ini dikelola secara keswadayaan, yang keberadaan nya menjadi sangat penting dan diperlukan masyarakat Kauman, Ngupasan, Gondomanan, Yogyakarta yang bersifat plural. Sapaan untuk anggota yang ada di SAKA FM ini adalah Balaswara, dan sapaan untuk pendengar nya adalah Sahabat Setia.

Tujuan didirikannya radio komunitas SAKA FM ini agar lahirnya kebersamaan, kerukunan di masyarakat dengan tanpa mengabaikan esensi nilai-nilai pluralis masing-masing. Melakukan aktifitas melalui penyiaran untuk mensukseskan program pemberdayaan pembangunan masyarakat. Pendirian radio komunitas ini sebagai penyadaran dan kebutuhan atas media yang independen untuk kepentingan komunitasnya.

Visi dari radio komunitas ini adalah memotivasi masyarakat dengan informasi dan hiburan yang cerdas, dalam pancaran silaturahim dari Kauman untuk semua. Lalu misi nya yaitu, menyampaikan informasi dan pendidikan yang baik, akurat dan benar kepada masyarakat untuk terjaganya nilai kebersamaan, kerukunan, keterbukaan dan demokratis. Mensosialisasikan dan membina nilai-nilai persaudaraan kepada masyarakat Kauman Ngupasan dan sekitarnya. Terwujudnya silaturahmi, persatuan, persaudaraan dan keterbukaan masyarakat di Sleman sebagai wujud implementasi dari nilai kemanusiaan dalam bermasyarakat, berbangsa dan beragama. Terwujudnya siaran radio yang menghibur dan mendidik kepada masyarakat.

Agar menjawab permasalahan mengenai gaya kepemimpinan station manager SAKA FM ini, penulis menggunakan 2 informan. Informan pertama ini bernama Totok Yulianto, atau panggilan akrabnya Ali. Pria berumur 33 tahun ini, merupakan lulusan S1 dari salah satu universitas di Yogtakarta. Sejak tahun 2019 lalu beliau diangkat menjadi seorang station manager di Radio Komunitas Saka FM. Namun sebenarnya dia sudah bergabung di 
radio ini sejak 2014 lalu, jadi sudah 7 tahun bergabung. Jabatan yang sedang ia jalankan ini akan dijalani selama 3 tahun, terhitung dari tahun 2019 hingga 2021 nanti. Proses pengangkatan manajer ini dilakukan dengan musyawarah besar yang dilakukan selama tiga tahun sekali.

Informan yang kedua adalah Agus Ali Syafaat, dengan panggilan akrabnya Agus. Melalui informan kedua ini, bertujuan untuk mengetahui bagaimana pandangan seorang bawahan nya alias disini sebagai penyiar terhadap gaya kepemimpinan pemimpin nya. Agus sudah bergabung menjadi penyiar di SAKA FM sudah 2 tahun lalu dengan program andalannya yaitu "Arisan Sat Set". Laki-laki berusia 23 tahun ini merupakan lulusan dari Universitan Islam Indonesia, Yogyakarta.

Berdasarkan wawancara yang dilakukan, dalam mewujudkan visi dan misi SAKA FM sang station manager melibatkan seluruh anggota atau divisi-divisi yang ada disana. Ali yakin bahwa radio ini berangkat dari komunitas, sehingga dalam mewujudkan visi dan misi perlu melibatkan seluruh anggota komunitas. Hal ini diperoleh dari hasil wawancara dengan Ali, berikut kutipannya:

\footnotetext{
"Visi dan misi SAKA itu tetap berangkat nya dari komunitas, ketika kita kemudian berangkat dari komunitas, maka ya harus sebisa mungkin, sebesar mungkin melibatkan komunitas, nggak bisa kalau visi dan misi komunitas dikerjakan dengan model one man gitu."
}

Berdasarkan wawancara, penulis mendapatkan data bahwa, Ali sebagai manajer dia sebenarnya lebih menyukai memimpin dengan model departemen divisi, jadi dia mengontrol masing-masing departemen. Namun karena di SAKA FM saat itu pada masa transisi, dimana para anggota masih bekerja dengan kultur non professional, namun dia berusaha mencapai supaya sistem yang sudah bisa dijalankan dengan baik.
Agar meningkatkan interaksi seorang manajer dengan para divisi setiap 1 hingga 3 bulan sekali diadakan rapat pleno, untuk membahas pencapaian SAKA FM saat ini dan membahasan hal-hal untuk kelanjutan SAKA kedepannya. Hal ini pun dibenarkan oleh informan kedua bahwa memang ada rapat setiap bulan. Dibawah ini merupakan kutipan wawancara dengan Agus:

\footnotetext{
"Ada sih, agendanya tiap minggu, nama nya Kamisan. Nah kamisan ini biasanya diadakan pas sore gitu, kita ntar makan-makan gitu, dan pastinya sambil ngobrol-ngobrol kan, basa-basi. Biasanya juga ada selipan perbincangan yang membahas untuk progres kedepannya. Kamisan ini sempat vakum, tapi sekarang udah gencar diadakan lagi. Ada juga sih rapat bulanan itu, tiap satu bulan sekali."
}

Sebagai pemimpin, Ali juga sangat memperhatikan penyiar-penyiar nya, ia mempunyai cara sendiri, dengan selalu menanyakan kesiapan para penyiar sebelum melakukan siaran. Berikut hasil wawancara dengan Ali:

\footnotetext{
"Hampir setiap hari saya mengontrol untuk penyiar-penyiar, misalnya besok siapa yang siaran, itu sudah pasti saya WA dulu, memastikan besok bisa siaran atau nggak, kalau nggak ya harus cari pengganti. Sering berkomunikasi lewat WA aja sih, dan saya hadir di studio dengan rentang yang cukup supaya teman-teman bisa saling berkomunikasi, dan mencoba bangun kultur tidak terlalu kaku karena ini modelnya komunitas ya."
}

Dalam wawncara diatas Ali menggunakan saran Whatsapp (WA) untuk menjalin komunikasi dengan penyiar. Hal diatas dibenarkan oleh Agus sang penyiar di SAKA FM, sebagaimana ucapan nya dalam wawancara:

"Oke, kalau menurut aku pribadi perhatian, karena Mas Ali itu selalu memantau perkembangan obrolan kita di grup WA programku "Arisan SAT SET". Terus kalau misalnya aku nggak siaran 
atau mau izin dan sebagainya, itu selalu memberi kabar di grup tersebut dan Mas Ali selalu memberi tanggapan nya, dan kalau nggak hadir juga selalu ditanya juga kenapa nggak siaran?"

Ali juga menerapkan bermain bersama dengan penyiar lainnya, untuk meningkatkan kedekatan nya, permainan ini biasa nya uno staco, warewolf dan masih banyak lagi. Ia juga mempunya visi untuk para penyiar agar menjadi sosok penyiaran yang hebat dan keren, maka dari itu ada beberapa kegiatan yang biasa dilakukan. Berikut hasil wawancara:

\begin{abstract}
"Ada visi untuk setiap penyiar itu, ketika di radio itu ada target capaian lah ya. Tapi bukan target pekerjaan si, tapi pencapaian bahwa teman-teman yang bergabung dengan SAKA ini bukan hanya sekedar mengisi siaran saja, tapi benar-benar menjadi penyiar yang bagus, maka ada upgrade skill yang didorong secara berkala, juga punya skill keradioan ya."
\end{abstract}

Hal diatas juga sejalan dengan pernyataan Agus dalam wawancara:

"Sebenernya kalau untuk arget berbuah hasil ke karya gitu, aku belum dapet target gitu. Kalau di aku lebih dituntut dalam siaran bisa membawa aura bahagia, terus positif, kayak gitu. Terus kan program ku arisan sat set, yang nanti tujuan nya itu membawa hal-hal positif tapi dikemas nya itu ngerumpi. Jadi itu sih lebih tekanan nya disitu. Mekanisme siaran dan teknik-teknik siaran itu lebih ditekankan."

Penulis juga mendapatkan data cara Ali dalam mengambil suatu keputusan, jika dianalisis, ia melibatkan pendapat dari para divisi lain dan juga penyiar-penyiar. Hal ini juga dibenarkan oleh informan kedua bahwa manajer tetap melibatkan divisi lain. Dibawah ini hasil wawancara dengan Ali:

"Dalam hal ini sering kali harus melibatkan teman-teman, baik dari divisi, sekedar untuk mendapat second opinion, biar apa yang saya putuskan itu paling tidak ada orang yang siap
melaksanakan, bukan keputusan
sepihak."

Berdasarkan hasil wawancara penulis juga mendapatkan data bahwa dalam menyelesaikan konflik, misalnya ada miss komunikasi dia mencoba membiarkan dulu, karena dia mempunyai pandangan bahwa konflik sebagai dinamisme organisasi, dan setiap konflik pasti ada jalan keluarnya. Berikut ungkapan Ali dalam wawancara:

\begin{abstract}
"Jadi kalau saya lebih suka yaudah biarin aja dulu, entah ntar ada miss komunikasi, ada yang marah-marah, yaudah biarin aja dulu, nanti akan ketemu jalan nya sendiri, kalau memang niat nya baik. Tapi kalau niat nya tidak baik, ya nanti biasa nya akan terlempar. Maka dari itu saya tidak terlalu ambil pusing lagi kalau ada orang yang tidak cocok, mau pindah dan sebagainya ya biasa aja, tapi sampai sekarang nggak ada konflik yang parah sih."
\end{abstract}

\section{Pembahasan}

Setiap pemimpin dalam sebuah organisasi mempunyai cara yang berbeda beda, oleh karena itu pada penelitian ini penulis menganalisis gaya kepemimpinan di Radio Komunitas SAKA FM Yogyakarta. Pemimpin disini disebut sebagai "station manager", tentunya seorang manajer mempunyai peran yang besar dalam kesuksesan suatu organisasi. Berdasarkan dari hasil penelitian berupa wawancara kepada sang manajer dan juga salah satu penyiar di SAKA FM, hasil analisis penulis jika dilihat pada teori kisi kepemimpinan dalam buku Miller (2012), menunjukkan bahwa gaya kepemimpinan manajer SAKA FM adalah "Gaya Tim". Beberapa temuan yang mendasari penetapan gaya tim adalah, Ali sangat perhatian dengan penyiar dan divisidivisi lain, perhatiannya tersebut ditunjukkan dengan selalu menanyakan kesiapan penyiar sebelum siaran. Dalam Miller (2012: 50) dijelaskan bahwa Blake dan Moton percaya bahwa manajer dalam sebuah organisasi harus mengadopsi gaya tim ini untuk 
memaksimalkan perhatian baik terhadap produksi maupun orang nya.

Mempunyai cara untuk tetap berinteraksi dengan semua elemen dalam organisasi, dari hasil wawancara Ali menjelaskan bahwa dia melakukan permainan Bersama hingga melakukan rapat pleno. Selain itu Ali juga memanfaatkan perkembangan teknologi dan informasi, salah satunya menggunakan whatsapp untuk tetap terhubung dengan penyiar dan divisi lainnya. Hal ini dilakukan untuk menanyakan kabar hingga kesiapan pernyiar sebelum melakukan siaran pada jadwal yang sudah ditentukan. Bentuk nyatanya, ia terjun langsung melihat para penyiar di studio saat siaran dengan beberapa waktu yang cukup, sehingga bisa digunakan untuk bertemu dan berinteraksi dengan para penyiar. Mengutip dalam Iskandar (2019: 38) aset yang sangat penting bagi perusahaan adalah pegawai. Maka dari itu mereka harus dikelola dan dikembangkan dengan baik, agar memberikan kontribusi yang maksimal bagi organisasi.

Rasa saling menghargai setiap pekerjaan dan juga pada penyiar, dibuktikan dengan adanya visi sang manajer agar para penyiar tidak hanya sekedar mengisi siaran, melainkan bisa menjadi penyiar yang hebat. Berdasarkan hasil wawancara bisa dianalisis pula cara mengapresiasi kerja penyiar dia berusaha untuk terus mendorong keahlian yang dimiliki penyiar nya, seperti yang diungkapkan Ali saat wawancara yaitu dengan mengadakan broadcasting class, pelatihan audio, memberi kesempatan bekerja sama dalam pembuatan Iklan Layanan Masyarakat. Selaras dengan faktor pendorong terwujud nya visi, misi serta tujuan organisasi adalah hubungan antara pemimpin dan bawahannya yang dilandasi trust dan respect, hal ini dikarenakan semua elemen organisasi bergerak kearah yang sama untuk mencapai tujuan (Iskandar, 2019:38).

Ali pun juga sering memberi motivasi kepada para penyiar, walaupun tidak secara langsung memberi motivasi, namun ia mempunyai cara untuk memberi motivasi tersebut. Melalui data wawancara menunjukkan cara Ali untuk memotivasi yaitu pendekatan personal, ia melihat kondisi personal, kemudian sering berbincang bersama. Jika dengan penyiar yang baru masuk, dia terjun langsung dalam masalah pelatihan, sehingga saat para penyiar benarbenar sudah masuk dan aktif di radio, dia dengan mudah mendekati sebagai bentuk keperduliannya.

Cara station manager SAKA FM untuk memengaruhi perilaku bawahan nya ini sesuai dengan konsep menurut Madiistriyatno (2019: 25) bahwa terdapat dua cara yang bisa dilakukan oleh seorang pemimpin dalam memengaruhi perilaku pengikut nya, yaitu dengan perilaku mengarahkan, artinya sejauh mana seorang pemimpin melibatkan komunikasi satu arah, dengan menetapkan peranan yang seharus nya dilakukan oleh bawahan nya, kemudian dengan memberitahu bawahan nya apa yang harus dikerjakan, kapan, bagaimana, dimana serta melakukan pengawasan secara ketat. Kemudian yang kedua adalah perilaku mendukung merupakan dimana seorang pemimpin melibatkan dirinya dalam komunikasi dua arah. Seperti contoh dengan mendengarkan, memberikan dukungan atau dorongan, memudahkan segala interaksi, dan melibatkan bawahan dalam mengambil keputusan.

Dalam memutuskan suatu hal, Ali memang sudah mempunyai pandangan tersendiri untuk memutuskan suatu hal tersebut. Namun dia tetap meminta pendapat dan mendengarkan pendapat atau gagasan dari divisi lainnya dalam memutuskan suatu hal. Berdasarkan wawancara ia memang mempunyai anggapan bahwa jika ada pendapat dari orang lain, berarti ada orang yang siap melaksanakan, apa yang menjadi kesepakatan tersebut, karena kesepakatan nya tidak sepihak.

\section{PENUTUP}

Radio komunitas merupakan siaran radio yang orientasi nya dari komunitas untuk 
komunitas, diatur pula dalam UU No.32 tahun 2002 tentang Penyiaran. Pemimpin mempunyai pengaruh besar dalam berlangsung nya organisasi. Oleh sebab itu setiap pemimpin harus tepat menggunakan gaya kepemimpinannya. Pemimpin bebas menentukan gaya kepemimpinan yang dipilih karena sebagai ciri khas pemimpin tersebut. Berdasarkan analisis yang dilakukan kepada station manager SAKA FM ini menggunakan gaya tim (team style) dimana dicirikan dengan sang manajer memberikan perhatian terhadap tugas atau produksi dan manusia. Hal ini berdasarkan hasil penelitian yang menunjukkan bahwa station manager SAKA FM meyakini visi dan misi radio komunitas ini bisa tercapai dengan kerjasama, serta kepercayaan dan saling menghargai. Setiap satu hingga tiga bulan sekali mengagendakan pertemuan untuk membicarakan perkembangan SAKA FM selain itu juga sebagai sarana meningkatkan interaksi antara manajer dengan divisi lainnya. Pemberian motivasi kepada penyiar serta divisi lain juga dilakukan. Kemudian manajer ini mempunyai visi agar penyiarnya terus berkembang dengan keahlian nya masing-masing. Dalam proses pengambilan keputusan tetap menggunakan pendapat dari divisi lain sebagai bahan pertimbangannya. Gaya tim ini menjadi gaya yang baik karena seimbang dalam memperhatikan produk serta manusianya.

\section{DAFTAR PUSTAKA}

BBC News Indonesia. 2017. Dua Pimpinan Pertamina dicopot karena 'tidak bisa bekerja sama'. https://www.bbc.com/indonesia/in donesia38851894\#: :text=Rapat\%20umu m\%20pemegang\%20saham\%20Pe rtamina,Wakil\%20Direktur\%20Ut ama\%20Ahmad\%20Bambang.

Hardani, dkk. 2020. Metode penelitian kualitatf \& kuantitatif. Yogyakarta: CV. Pustaka Ilmu Group
Hartanto, Adrian. 2016. Analisis Gaya Kepemimpinan pada PT. Sinar Saran Sukses. AGORA. 4(2), 140145

Iskandar, Deddy H. 2019. Pemimpin Bermakna: Pengaruh Karakteristik Pemimpin terhadap Kinerja dan Kepuasan Kerja. Jakarta: PT. Elex Media Komputindo

Jaringan Radio Komunitas Yogyakarta. 2021. Radio Komunitas. https://jrky.org/radio-komunitas/

Kompas. 2021. Studi Ungkap Kenapa Nokia Bangkrut.

https://www.google.com/amp/s/am p.kompas.com/tekno/read/2021/03/ 30/08060077/studi-ungkapkenapa-nokia-bangkrut

Kriyantono, Rachmat. 2014. Teknik Praktis Riset Komunikasi Disertai Contoh Praktis Riset Media, Public Relations, Advertising, Komunikasi organisasi, Komunikasi Pemasaran. Jakarta: Kencana Prenanda Group

Latifah, Zahra. 2021. Pentingnya Kepemimpinan dalam Organisasi, dala Prosiding Seminar Nasional Magister Manajemen Pendidikan UNISKA MAB. 1(1), 234-243

Lestari, Anna Puji, dkk. 2018. Eksistensi dan Gaya Kepemimpinan Radio Lokal. Jurnal Ilmu Komunikasi. 16(2), 105-114

Madiistriyatno, Harries. 2019. Pemimpin dan Memimpin. Yogyakarta: Bintang Pustaka Madani

Miller, Katherine. 2012. Organizational Communication. Approaches and Processes. Canada: Cengange Learning 
Rahmadi. 2011. Pengantar metodologi penelitian. Banjarmasin: Antasari Press

Ramadhan, Adi Muhammad. 2019. Peranan Station Manager dalam Mengembangkan Radio Komunitas di Politeknik LP3I Bandung. Jurnal Komversal. 5(2), 13-27.

Rumondor, Alex. 2011. Tantangan Kepemimpinan Manajerial Organisasi Perguruan Tinggi Prediktor Efisiensi Manajemen Sistem Pendidikan Nasional. Sociae Polites. Edisi Khusus, 21-40
Rusmini. 2017. Metode Penelitian: (Teori dan Aplikasi Kuaitatif, Kuantitatif, Mixed Methods, serta Research \& Development). Jambi : Pusat Studi Agama dan Kemsyarakatan (PUSAKA)

UU No.32 tahun 2002 tentang Penyiaran

Wahab, Abdul Aziz. 2015. Kepemimpinan dalam Perubahan dan Perkembangan Organisasi. Jurnal Elektika. 3(1), 3-8

Yusuf, A. Muri. 2017. Metode Penelitian Kuantitatif, Kualitatif, Dan Penelitian Gabungan. Jakarta: KENCANA 